\title{
Description of a new species and complementary description of a known species of Iphiseiodes De Leon (Acari: Phytoseiidae)
}

\author{
JEFERSON LUIZ DE CARVALHO MINEIRO ${ }^{1}$, TATIANE MARIE MARTINS GOMES DE CASTRO² \\ \& GILBERTO JOSÉ DE MORAES ${ }^{3}$ \\ ${ }^{1}$ Laboratório de Acarologia, Centro Experimental do Instituto Biológico. Rodovia Heitor Penteado, km 3. CEP 13092-543. Campinas. \\ São Paulo, Brazil.E-mail: jefmin@hotmail.com \\ ${ }^{2}$ Departamento de Fitossanidade, Universidade Estadual Paulista, Faculdade de Ciências Agrárias e Veterinárias, UNESP, CEP \\ 4884-900, Jaboticabal, SP, Brazil.E-mail: tatianemarie@yahoo.com.br \\ ${ }^{3}$ CNPq Researcher, Departamento de Entomologia e Acarologia, ESALQ-USP, CEP 13418-900. Piracicaba, São Paulo, Brazil. \\ E-mail:gjmoraes@esalq.usp.br
}

\begin{abstract}
Species of Iphiseiodes De Leon have been reported only from tropical and subtropical regions of the Americas. In this paper, a new species of this genus is described from southeastern Brazil and a complementary description is provided for Iphiseiodes saopaulus (Denmark \& Muma).
\end{abstract}

Key words: Acari, predatory mite, taxonomy, biological control

\section{Introduction}

A revision of Iphiseiodes De Leon was published by Aponte \& McMurtry (1995). At that time, it included five species: Iphiseiodes kamahorae De Leon, 1966, Iphiseiodes neonobilis Denmark \& Muma, 1978, Iphiseiodes nobilis (Chant \& Baker, 1965), Iphiseiodes quadripilis (Banks, 1904) and Iphiseiodes zuluagai Denmark \& Muma, 1972. Since then, two new species were described in this genus (Iphiseiodes setillus Gondim Jr. \& Moraes, 2001 and Iphiseiodes moraesi Ferla \& Silva, 2011) and two species originally described as Amblyseius Berlese (A. saopaulus Denmark \& Muma, 1973 and A. metapodalis El-Banhawy, 1984) were transferred into it (Chant \& McMurtry, 2004). A redescription of this genus was presented by Chant \& McMurtry (2004).

All of the species known to date in Iphiseiodes have been reported only from tropical and subtropical regions of the Americas (Moraes et al., 2004). Six of those species (I. metapodalis, I. moraesi, I. quadripilis, I. saopaulus, I. setillus and I. zuluagai) have been reported from Brazil. The most common of those is I. zuluagai, which has been reported from several different plants and seems to be an important predator of mite pests on citrus and coffee (Pallini Filho et al., 1992; Sato et al., 1994; Reis et al., 2000; Spongoski et al., 2005; Reis \& Zacarias, 2007).

The objective of this paper is to describe a new species of Iphiseiodes from southeastern Brazil and to provide a complementary description of I. saopaulus based on specimens collected from its type locality and other localities in the same region.

\section{Material and methods}

The species reported in this study were collected during an evaluation of the mite fauna of coffee and associated naturally occurring plants in the State of São Paulo. The mites were slide mounted in Hoyer's medium for microscopic examination.

Setal nomenclature used for the dorsal and ventral idiosoma in this paper follows that of Rowell et al. (1978) and Chant \& Yoshida-Shaul (1991), respectively. Measurements are given in micrometres; the measurement pre- 